\title{
The Life History of Thysanoessa raschii.
}

\author{
By \\ Roderick Macdonald, M.A., B.Sc., B.Sc.(Agric.). \\ Research Fellow, Marine Biological Station, Millport.
}

With Seven Plates.

INTRODUCTION.

Thysanoessa raschii (M. Sars).

Synonyms-Thysanopoda raschii M. Sars, Euphausia raschii G. O. Sars, Boreophausia raschii Norman, Rhoda jardineana Sim, Scott, Rhoda raschii $\mathrm{H}$. J. Hansen, Thysanoessa raschii $\mathrm{H}$. J. Hansen.

Thysanoessa raschii is a regular inhabitant of the Firth of Clyde. Adults are found throughout this area, generally in waters not less than $40 \mathrm{fms}$. deep. Those of large size, $23-25 \mathrm{~mm}$., are apparently consistently found from year to year in Loch Striven in large numbers from October to January within $10 \mathrm{fms}$. from the bottom in waters of $40 \mathrm{fms}$. depth. Throughout the rest of the year they occur in small numbers in the tow-nets, and are seldom found at all during the summer months. On one occasion, however, February, 1926, several hundreds were fished in addition to large numbers of Meganyctiphanes norvegica at 40-60 fms. in the Cumbrae Deep. T. raschii has two spawning periods in the year; the first from the end of February to the middle of May, the second from the middle of August to the middle of September. These spawning periods may vary by a few weeks in time of commencement and duration from year to year. Eggs are found near the surface, and are specially abundant and most consistently found over depths not less than $40 \mathrm{fms}$. As is the case with $M$. norvegica, I find that in daylight at all depths during spawning adult specimens are rarely found in the tow-nets, even in those areas where eggs or larvæ are abundant. The appearance of large numbers of adult $T$. raschii in the tow-nettings from Loch Striven shortly after autumn-spawning has ceased is very striking. This congregation of individuals continues till early spring, as mentioned above, when the numbers caught are considerably reduced. From March till the end of the autumn-spawning period, when large numbers again appear in Loch Striven, adults are rarely obtained in the tow-nets. From material in the Museum at Millport Marine Station I have found 
a characteristic large haul of $T$. raschii made in Loch Striven by the late Sir John Murray in October, 1887. It is strange that during spring, when eggs are found in greatest abundance, adult specimens are rarely fished in the tow-nets. With regard to the occurrence of $T$. raschii and $T$. inermis in the Barents Sea, Mielck (1913) says "Large numbers of nauplii and other larval stages of Euphausids appeared on the surface north and north-west of Kanin and in a remarkable manner at those stations where adult forms were absent." Sars also states, "It is here worthy of note, that in those places at Drobak (Oslofjord, Norway), where the ova occurred in great abundance, not a single adult Euphausid was ever found." Bigelow (1924, p. 155) remarks, when dealing with the distribution of Euphausids in the Gulf of Maine, U.S.A., "However, larval Euphausids of any sort have always been very rare in our offshore catches in the north-eastern part of the Gulf notwithstanding the constant presence of the adults there." With regard to T. raschii, Bigelow (1924, p. 143) states that they are found in great abundance in the Gulf of Maine during March and April, but are rare in summer. It appears from my observations that $T$. raschii congregate in large numbers under various impulses, but that on mating during such a " congregation" in spring or autumn they distribute themselves in small groups over a particular area where the females shed their eggs. When spawning ceases, they may congregate once more in large numbers. It may be that sexually mature adults spawn on or immediately above the bottom, and that the pressure found at those depths, 40-70 fms., is specially favourable to mating or spawning. It may also be suggested that they spawn nearer the surface at night during their vertical migrations, and then descend to the bottom, close to which they remain during the day throughout the spawning period. By keeping close to the bottom they would not be caught readily by present methods of tow-netting, and accordingly their scarcity during summer may be less real than is supposed. Russell (1927, p. 605) has drawn attention to the danger of drawing conclusions about seasonal abundance of macroplankton from daylight hauls.

There are two sizes of breeding individuals. Mature males are found measuring ca. $13 \mathrm{~mm}$., whereas immature males also occur measuring ca. $19 \mathrm{~mm}$. (Plate III, Figs. 10 and 16). A few immature males measuring $25 \mathrm{~mm}$. have been found. The total catches indicate that the two sizes of sexually mature individuals are $13 \mathrm{~mm}$. and $21 \mathrm{~mm}$. respectively. Those immature males measuring $25 \mathrm{~mm}$. may be abnormal, or again may be examples of normal senescence. Lebour (1926, p. 9) also finds two sizes of breeding individuals in $T$. inermis, the larger breeding individuals being found in the Atlantic, whereas the smaller are found in the Channel, parts of Norway, and near Aberdeen. 


\section{The Life History of T. raschii.}

The life history of $T$. raschii agrees very closely with that of $T$. inermis described by Lebour (1926). The material was obtained chiefly from Keppel Pier and Loch Striven. The majority of the stages were examined while yet alive. One-celled eggs were found in the tow-nets, and these developed in captivity to the second nauplius. The nauplius and metanauplius were recognised in the plankton, and developed in captivity to the first and second calyptopis. By this method of intercalation of stages the complete life cycle was worked out. The furcilia forms tended to be caught on the surface film of water in the glass vessels in which they were kept. The cyrtopia forms, on the other hand, no doubt because of the presence of well-grown pleopods, which enabled them to be more powerful swimmers, were not found lying helpless in the surface film, and seldom left the bottom of the glass globe. The young adults, as with the fully grown specimens, were almost invariably found at the bottom of the glass tank where the light was least intense, although at varying intervals they made short excursions towards the surface.

The "eggs" vary in size, the diameter of the outer shell measuring .40 to $\cdot 60 \mathrm{~mm}$., while the egg proper measures $.35 \mathrm{~mm}$. in the unsegmented stage to $.38 \mathrm{~mm}$. in the segmented and young embryo stages (Plate I, Figs. 1-4). The wall of the outer shell has a double contour, the distance between the contour lines measuring $3 \mu$. Brook and Hoyle (1888) have observed this double contour. This double contoured appearance may be due to the relatively great thickness of the outer shell wall. The egg is spherical and perfectly transparent during the early stages of segmentation. Presently a very localised carmine pigmentation is seen where division is most active. When the blastopore is formed and the egg is suitably placed under the microscope the pigment material is seen to fill up the blastopore, demarcating it very distinctly, and spreading out in a somewhat scattered fashion over the surface of the egg in the immediate neighbourhood of the blastopore. When viewed from above the egg appears to have an intensely red pigment spot on its surface. This spot is characteristic. As development proceeds the pigmentation almost disappears, leaving a faint tinge on the posterior end of the unhatched nauplius. These last traces of pigmentation usually disappear in the newly hatched nauplius. So far I have not found an egg in the one-celled stage whose outer shell measures more than $48 \mathrm{~mm}$. in diameter. All sizes of eggs have been found from the mouth to the head of Loch Striven. The smaller eggs, $c a \cdot \cdot 40-48 \mathrm{~mm}$., are much more abundant than the larger eggs. It will be noted that the variation in the apparent size of the egg of $T$. raschii is due to an enlargement of the outer capsule, the egg itself varying very slightly, viz. $.03 \mathrm{~mm}$. The larger eggs had 
frequently the appearance figured by Lebour, 1924, (Plate V, Figs. 3, 5, and 6,) and as suggested by that author are probably abnormal. When describing the eggs of the forms T. inermis and T. neglecta, Lebour (1924, p. 415) states, "It is, however, the size of these eggs which is quite different in the two forms that primarily warrants one regarding them as distinct species." In both forms, however, it is merely in the size of the outer shell that Lebour finds such a great difference, the egg proper measuring in each form $.32 \mathrm{~mm}$. in diameter. From my observations on eggs of $M$. norvegica and $T$. raschii it would appear that the size of the egg itself is a more relliable specific character. Lebour (1926, p. 2) finds that the eggs of $M$. norvegica found in the Atlantic are rather smaller than those from the Channel. Many more observations in widely separate geographical areas where Euphausid eggs are found must be made before it can be determined what causes this variation in diameter of egg capsule. In this connection it is interesting to note Sollaud's (1922, p. 3) observations on Palæmon eggs. He says that the number of eggs contained in the same laying necessarily bears a relation to their volume, and suggests that this volume is perhaps very different in one species from that of another and may similarly vary according to the geographical race of the same species. He also says that a large number of Palæmon, especially those with a very wide distribution and which frequent supralittoral brackish waters, have the size of the eggs reduced, whereas many fresh-water inhabiting Palæmon spawn very largesized eggs.

The nauplius gradually develops within the egg capsule, which may increase in size before the nauplius ultimately becomes free swimming. Shortly before hatching the nauplius sets itself free from the vitelline membrane, and can be seen making intermittent jerking movements with its appendages which are now capable of free movement. Ultimately the spines on the appendages tear open the capsule and the nauplius is set free.

\section{NAUPLIAR Forms.}

The naupliar forms are of a more slender build than those of $M$. norvegica, and conform more closely to those of $T$. inermis figured by Lebour (1926, Plate I, Figs. 1 and 2). The newly hatched nauplius (Plate I, Fig. 5) measures 45 to $47 \mathrm{~mm}$. in length, and has three pairs of typical biramous swimming appendages. This form gives rise to the second nauplius (Plate I, Fig. 7), which measures 47 to $49 \mathrm{~mm}$. in length. The naupliar eye has now appeared, and there is a foreshadowing of the paired eye of the adult form. Two pairs of short and one pair of long setæ are present at the posterior extremity of the body. In this last point it resembles the second nauplius of Meganyctiphanes (Macdonald, 
1927, Plate I, Fig. 6), but differs from the second of the latter as figured by Lebour (1924, Plate IV, Fig. 4), and from the second nauplius of T. inermis as figured by Lebour (1926, Plate I, Fig. 2). The second nauplius gives rise to the metanauplius.

\section{Metanauplius.}

This is characteristically slender in form and quite different from the metanauplius of Meganyctiphanes, which is stouter and whose dorsal face has in the middle what Sars (1898, p. 20) described as " an almost gibbous prominence." The metanauplius measures $56 \mathrm{~mm}$. (Plate I, Figs. 6 and 8). The carapace which is bordered by spines, for the most part regular, covers the body expanding in front to cover the eyes and lying close to the body posteriorly. The telson has six terminal spines and four pairs of lateral spines (Plate IV, Fig. 1). In other respects the metanauplius agrees with that of $T$. inermis, as described by Lebour (1926, p. 3).

\section{Calyptopis Stages.}

The first calyptopsis arises from the metanauplius. There are three calyptopis stages, all of which are characteristically slender in form and perfectly transparent apart from two pairs of red chromatophores which appear on the telson.

First calyptopis (Plate II, Figs. 2 and 8) measures $.96-1.02 \mathrm{~mm}$. in length. The telson has six terminal spines (Plate IV, Fig. 2). A distinct protuberance is seen dorsally near the centre on the carapace. The abdomen is unsegmented.

Second calyptopis (Plate II, Figs. 1 and 9) measures 1.8-2.00 mm. in length. The telson has now seven terminal spines. It is noted that there is a tendency for the long outer lateral spines to approximate more closely in length to that of the inner spines (Plate IV, Figs. 1-4). In the cyrtopia stages the outer lateral spines are distinctly longer than the inner lateral spines. From my observations this stronger development of outer lateral spines is characteristic of $T$. raschii and $T$. inermis, and distinguishes the larvæ of these species from the larvæ of Meganyctiphanes and Nyctiphanes couchii. There is no trace of a lateral denticle on the carapace. The dorsal protuberance on the carapace is still distinguishable. The first thoracic limb is present. The abdomen has now five segments, and the segments of the thoracic region are indicated by small divisions.

Third calyptopis (Plate II, Fig. 10, and Plate VII, Fig. 1) measures 2.4 to $2.5 \mathrm{~mm}$. in length. The abdominal segments are now six in number. The uropods are seen distinctly. There is still no lateral denticle on the 
carapace. The first thoracic limb is well developed. No more thoracic limbs are present. The compound eye has increased in development. It is noted that in different specimens there is a varying amount of black pigment present in the eyes.

\section{The Furcilia Stages.}

I have found fourteen different "stages," but whether one individual goes through every stage or not has not been proved. All the stages are typically siender in form and transparent, but for two pairs of red chromatophores on the telson, slight red pigmentation on mouth parts and diffuse orange-red spots which are seen while the pleopods are still buds, close to where the luminescent organs ultimately appear. The development of the pleopods corresponds to that of $T$. inermis (Lebour, 1926 , p. 6). The lateral denticle on the carapace may not appear till the fifth furcilia, although I have found it present several times as early as the first furcilia. This late appearance of the lateral denticle in a species in which the lateral denticle is present in the adult form is singular. With regard to $T$. inermis, Lebour $(1926$, p. 6) says, " No lateral denticle is present in any stage, which is interesting, as it occurs in other species of different genera when lacking in the adult, but here it agrees with Stylocheiron, which has no lateral denticle in any stage." The development of the furcilia stages agrees very closely with that of $T$. inermis

First furcitia (Plate II, Fig. 11, and Plate VII, Fig. 2) ; measures $3 \cdot 1-3 \cdot 2 \mathrm{~mm}$. in length. The eyes are free and no pleopods are present. There are seven terminal spines on the telson of all the furcilia stages (Plate IV, Figs. 5-7).

Second furcilia ; $3.4 \mathrm{~mm}$. in length and has one pair of simple non-setose pleopods.

Third furcilia ; $3.4 \mathrm{~mm}$. long with two pairs of simple non-setose pleopods.

Fourth furcilia; $3.5 \mathrm{~mm}$. long with three pairs of simple non-setose pleopods.

Fifth furcilia ; $3.6 \mathrm{~mm}$. long with four pairs of simple non-setose pleopods.

Sixth furcilua (Plate VII, Fig. 3 ) ; $3 \cdot 6-3.9 \mathrm{~mm}$. long with five pairs of simple setose pleopods.

Seventh furcitia; $3 \cdot 8-4.0 \mathrm{~mm}$. long with one pair setose pleopods and four pairs of simple pleopods.

Eighth furcilia ; $4.0 \mathrm{~mm}$. long with two pairs of setose pleopods and three pairs of simple pleopods.

Ninth furcilia; $4.05 \mathrm{~mm}$. long with three pairs of setose pleopods and two pairs of simple pleopods.

Tenth furcitia; $4.5 \mathrm{~mm}$. long with four pairs of setose pleopods and one pair of simple pleopods. 
Eleventh furcilia ; $4.6 \mathrm{~mm}$. long with five pairs of setose pleopods.

Twelfth furcilia; $4.6 \mathrm{~mm}$. long. The fourth thoracic limb jointed while fifth still a bud. Second thoracic and first abdominal luminescent organs present.

Thirteent $\operatorname{n}$ furcilia; 4.8-5.0 mm. long. Fifth thoracic limb jointed and sixth just indicated by a simple bud. Second abdominal luminescent organ appears.

Fourteenth furcilia; $5 \cdot 1-5 \cdot 2 \mathrm{~mm}$. long. Thoracic limbs slightly more developed than in the thirteenth furcilia. The sixth thoracic limb is still unsegmented. Mandibular palp indicated by a small bud (Plate VI, Fig. 5). Third abdominal luminescent organ present.

\section{Cyrtopia Stages.}

The cyrtopia stages are easily recognised by the increased development of the antennules and antennæ, the formation of the scale in the latter being characteristic. The mandibular palp, though still a bud in the first cyrtopia, develops rapidly in the succeeding stages, and ultimately assumes the adult form in the twelfth cyrtopia. The lateral denticle on the carapace, which was somewhat posteriorly placed in the furcilia stages, now takes the median position. In the adult form the lateral denticle is anterior to the median position. The rostrum becomes narrower, approximating to that of the adult form (Plate II, Figs. 3, 4, 5). The telson becomes narrower, and shows reduction in the number of terminal spines. The first cyrtopia has seven terminal spines. The second cyrtopia has five terminal spines, the azygous spine being jointed. In the third cyrtopia there are five terminal spines, but here the median spine may be considerably reduced in size and is unjointed (Plate IV, Figs. 8, 9, 14, and 15). The reduction in numbers of the terminal spines may not be symmetrical (Plate IV, Figs. 18 and 19). The long outer lateral spines are absent in the sixth cyrtopia. I have found an indication of "jumping" of stages. The third cyrtopia may be omitted, the second cyrtopia giving rise directly to the fourth cyrtopia (Plate IV, Fig. 10).

The development of the thoracic region is closely similar to that found in T. inermis by Lebour (1926). In the first cyrtopia, the second thoracic leg is slightly longer than the first thoracic leg. As development proceeds this difference in length becomes less until, in the adult form, the difference in length is negligible (Plate VI, Figs. 7 and 8 ; Plate III, Figs. 1 and 2). Thus there is no indication of a greatly lengthened second thoracic limb as is found in $T$. inermis form neglecta.

As in T. inermis (Lebour, 1926, p. 7) it is interesting to note that the endopodite on the seventh thoracic leg is formed after the exopodite. 
The form of the endopodite is different in both sexes at a very early stage in development. The endopodite may appear in the twelfth cyrtopia stage. The endopodite on the seventh thoracic leg of the adolescent male $13 \mathrm{~mm}$. long is a rounded bud bearing six or seven spines. The corresponding endopodite of a similar sized female is also a bud, but this bud is narrowed towards the end where there is a conspicuous spine (Plate VI, Fig. 6 ; Plate III, Fig. 3). In the adult, the endopodite of the seventh thoracic leg of the female develops more rapidly than that of the male (Plate III, Figs. 5 and 6).

As has been stated earlier there are two sizes of breeding individuals. Fully modified males have been found $13 \mathrm{~mm}$. long. The secondary sexual modification on the first pair of pleopods in a male $13 \mathrm{~mm}$. long may not only be as fully developed, but as large as that found on a male considerably larger, e.g. $20 \mathrm{~mm}$. long.

The following is a list of the cyrtopia stages which I have found :-

First cyrtopia; 5·3-6.00 mm. long. Seven terminal spines on telson. Fourth abdominal luminescent organ present.

Second cyrtopia; 6.2-6.4 mm. long. Five terminal spines on telson.

Median spine jointed. Luminescent organ present at base of seventh thoracic leg.

Third cyrtopia ; 6.4-6.5 mm. long. Five terminal spines on telson. The median spine is unjointed.

Fourth cyrtopia ; $6 \cdot 6-6 \cdot 95 \mathrm{~mm}$. long. Three terminal spines on telson.

Fifth cyrtopia; $7 \cdot 0-7 \cdot 4 \mathrm{~mm}$. long. One terminal spine on telson.

Sixth cyrtopia; $7 \cdot 5-7 \cdot 8 \mathrm{~mm}$. long. Outer pair of long lateral spines have disappeared.

Seventh cyrtopia; 8.0-8.45 mm. long.

Eighth cyrtopia ; $8 \cdot 9-9 \cdot 20 \mathrm{~mm}$. long.

Ninth cyrtopia; $9 \cdot 5-9.85 \mathrm{~mm}$. long.

Tenth cyrtopia ; $10-10 \cdot 20 \mathrm{~mm}$. long.

Eleventh cyrtopia; 10.5-10.95 mm. long.

Twelfth cyrtopia ; 11-11.5 mm. long.

I have great pleasure in recording my thanks to Professor J. Graham Kerr, F.R.S., for helpful advice, and to His Grace the Duke of Argyll for the much appreciated facilities afforded in the Castle for carrying out my work during numerous visits to Inveraray, Loch Fyne. I am indebted to the Carnegie Trustees for financial assistance which made my work possible. 


\section{LITERATURE.}

Bigelow, H. B. 1926. Plankton of the Offshore Waters of the Gulf of Maine. Bulletin of the Bureau of Fisheries, Washington. Vol. XL, 1924, Part II.

Brook, G., ANd Hoyle, W. E. 1888. The Metamorphosis of British Euphausiidæ. Proc. Roy. Soc. Edinburgh, July 2.

Lebour, M. V. 1926. The Euphausiidæ in the Neighbourhood of Plymouth. III, Thysanoessa inermis. Journ. Mar. Biol. Assoc., Vol. XIV, No. 1.

MAcdonald, R. 1927. Irregular Larval Development in Meganyctiphanes norvegica. Journ. Mar. Biol. Assoc., Vol. XIV, No. 3.

Mielck, W. 1913. Wissentschaftliche Meeresuntersuchungen. Vols. XII, XIII. Untersuchungsfahrt Juni, Juli, 1913, pp. 40-41.

Russeld, F. S. 1927. The Vertical Distribution of Marine Macroplankton. V. The Distribution of Animals caught in the Ring-trawl in the Daytime in the Plymouth Area. Journ. Mar. Biol. Assoc., Vol. XIV, No. 3.

SARS, G. O. 1898. On the Propagation and Early Development of Euphausiidæ. Archiv. Math. Naturvid, B. XX, No. 11.

Sollaud, E. 1922. L'Embryogenie des Crustacés Décapodes. Supplements au Bulletin Biologique de France et de Belgique. 


\section{EXPLANATION OF PLATES.}

Figures in Plate I and Figs. 1 and 2 in Plate II all drawn to same scale. Figures in Plates III, V, and VI all drawn to same scale.

\section{PLATE I.}

Thysanoessa raschii.

FIG. 1.-One-celled egg-outer shell $40 \mathrm{~mm}$. in diameter. Ovum $35 \mathrm{~mm}$. in diameter. FIG. 2.-Segmented egg - outer shell $\cdot 48 \mathrm{~mm}$. in diameter. Ovum $\cdot 38 \mathrm{~mm}$. in diameter. FIG. 3.-Egg with developing nauplius. Egg $44 \mathrm{~mm}$. in diameter.

Frc. 4.-The same egg as above showing nauplius further developed. Egg $50 \mathrm{~mm}$. in diameter.

FIg. 5.-First nauplius $45 \mathrm{~mm}$. long.

FIG. 6.-Metanauplius (side view) $\cdot 56 \mathrm{~mm}$. long.

FIG. 7.-Second nauplius $47 \mathrm{~mm}$. long.

FIc. 8.-Metanauplius (ventral view) $.56 \mathrm{~mm}$. long. 
PLATE I.
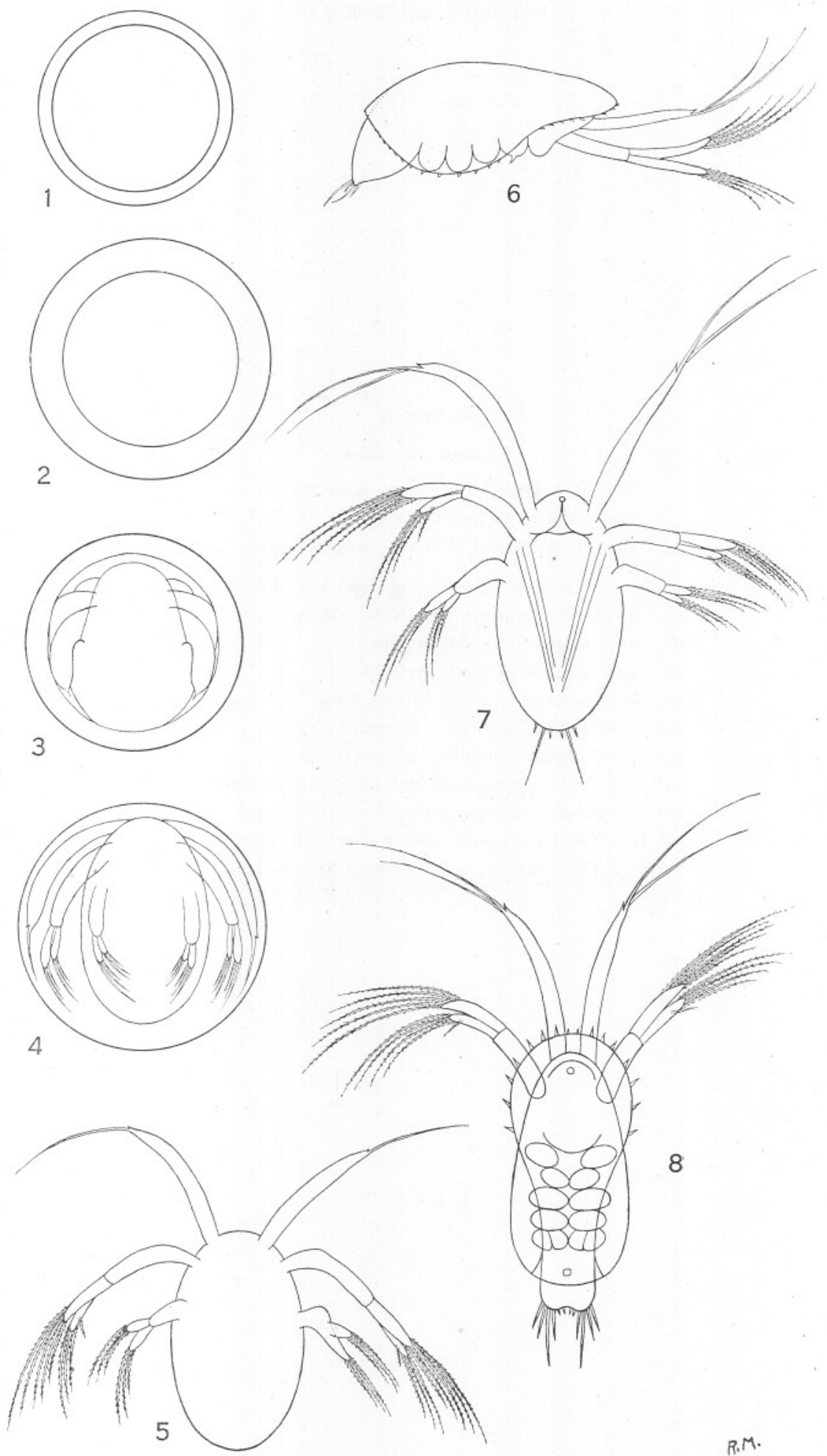

R.M. 
PLATE II.

Thysanoessa raschii.

Figs. 3, 4, 6, and 7 drawn to same scale.

Fig. 5 drawn to half this scale.

Figs. 8, 9, 10, and 11 drawn to same scale.

FIG. 1.-Second calyptopis (side view) $1.85 \mathrm{~mm}$. long.

FIG. 2.-First calyptopis (side view) $.98 \mathrm{~mm}$. long.

FIG. 3.-Carapace of sixth furcilia.

FIG. 4.-Carapace of tenth cyrtopia.

Fig. 5.-Carapace of adult $19 \mathrm{~mm}$. long.

Fig. 6.-Rostrum of adult $+19 \mathrm{~mm}$. long.

Fig. 7.-Rostrum of adult $\hat{\circ} 22 \mathrm{~mm}$. long.

FIG. 8.-First calyptopis (dorsal view) $1 \mathrm{~mm}$. long.

FIG. 9.-Second calyptopis (dorsal view) $1.95 \mathrm{~mm}$. long.

FIG. 10.-Third calyptopis (dorsal view) $2.40 \mathrm{~mm}$. long.

FIg, 11.-First furcilia (dorsal view) $3 \cdot 10 \mathrm{~mm}$. long. 
PLATE II.
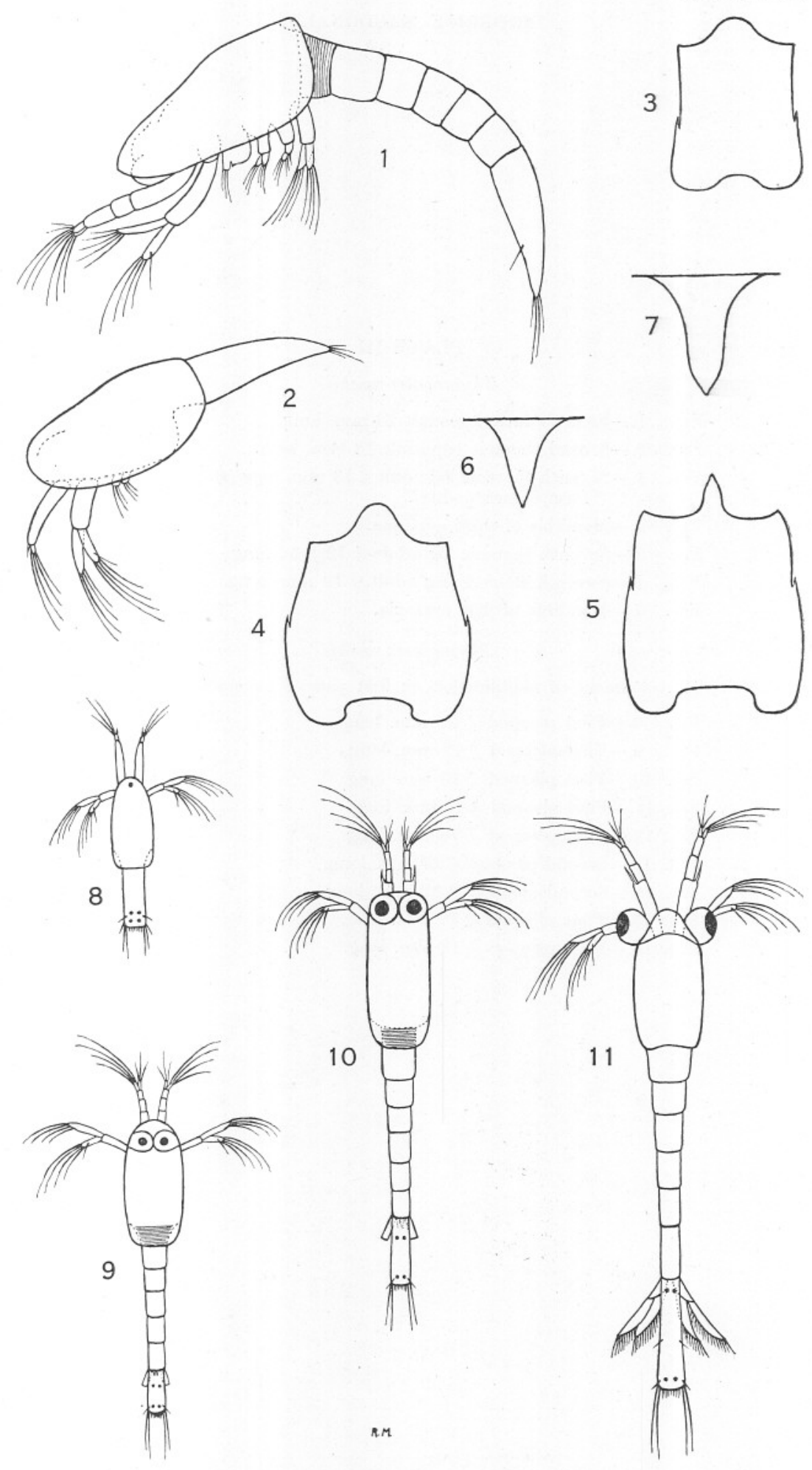
PLATE III.

Thysanoessa raschii.

Fig. 1.-First thoracic leg adult $18 \mathrm{~mm}$. long.

FIG. 2.-Second thoracic leg adult $18 \mathrm{~mm}$. long.

FIG. 3.-Seventh thoracic leg adult ㅇ $13 \mathrm{~mm}$. long (showing characteristic form of endopodite).

FIG. 4.-Mandible of third cyrtopia.

FIG. 5.-Seventh thoracic leg adult ô $19 \mathrm{~mm}$. long.

Fig. 6.-Seventh thoracic leg adult $q 19 \mathrm{~mm}$. long.

FIG. 7.-Mandible of first cyrtopia.

\section{Thysanoessa raschii.}

(Development of modification on first pair of pleopods in male.)

Fig. 8.-First pleopod ô $22 \mathrm{~mm}$. long.

Fic. 9.-First pleopod ô $12 \mathrm{~mm}$. long.

FIG. 10.-First pleopod ô $13 \mathrm{~mm}$. long.

Fia. 11.-First pleopod $\delta 15 \mathrm{~mm}$. long.

Fig. 12.-First pleopod ô $16 \mathrm{~mm}$. long.

Fig. 13.- Second pleopod ô $17 \mathrm{~mm}$. long.

Fig. 14.- Second pleopod ô $22 \mathrm{~mm}$. long.

Fig. 15.-First pleopod ô $17 \mathrm{~mm}$. long.

Fic. 16.-First pleopod $\hat{\sigma} 13 \mathrm{~mm}$. long. 
PLATE III.

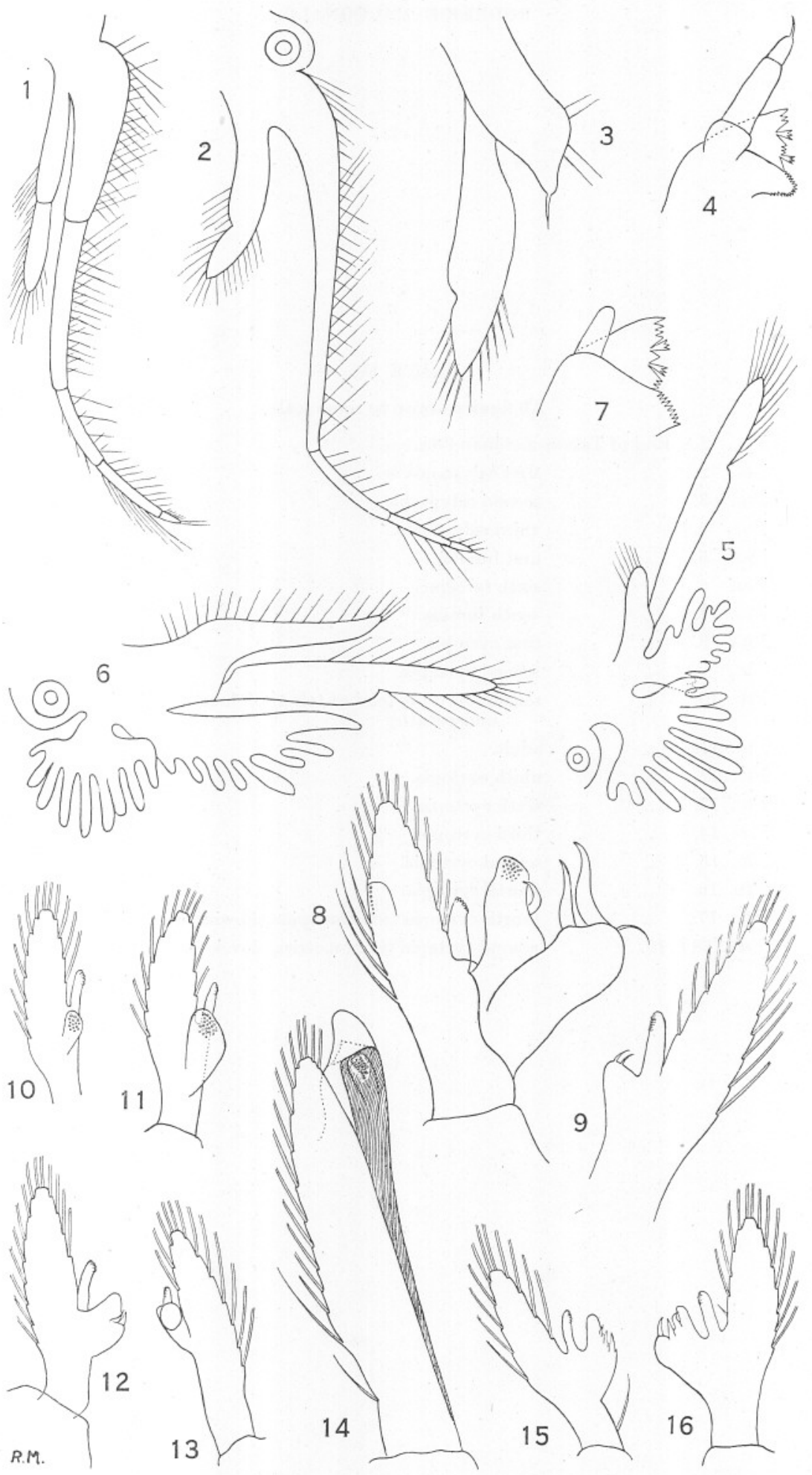




\section{PLATE IV.}

All figures drawn to same scale.

Fig. 1.-End of Telson metanauplius.

FIG. 2. , , , first calyptopis.

FIG. 3. , , second calyptopis.

FIG. 4. , , third calyptopis.

Fra. 5. , , , first furcilia.

Fig. 6. , , , sixth furcilia.

Fig. 7. , , , tenth furcilia.

FIG. 8. , , , first cyrtopia.

FIG. 9. ", ", second cyrtopia.

Fig. 10. " " $\quad$, second cyrtopia (end of telson of fourth cyrtopia showing

Fig. 11. , , , adult.

Fig. 12. " " , ninth cyrtopia.

Fig. 13. " " ", sixth cyrtopia.

Fig. 14. , " , third eyrtopia.

Fig. 15. , , , second cyrtopia.

FIG. 16. , , , fourth cyrtopia.

FIG. 17. , , , fourth cyrtopia (median spine showing less development).

Fias. 18 \& $19 . \quad$, second cyrtopia (asymmetrical development). 
PLATE IV.
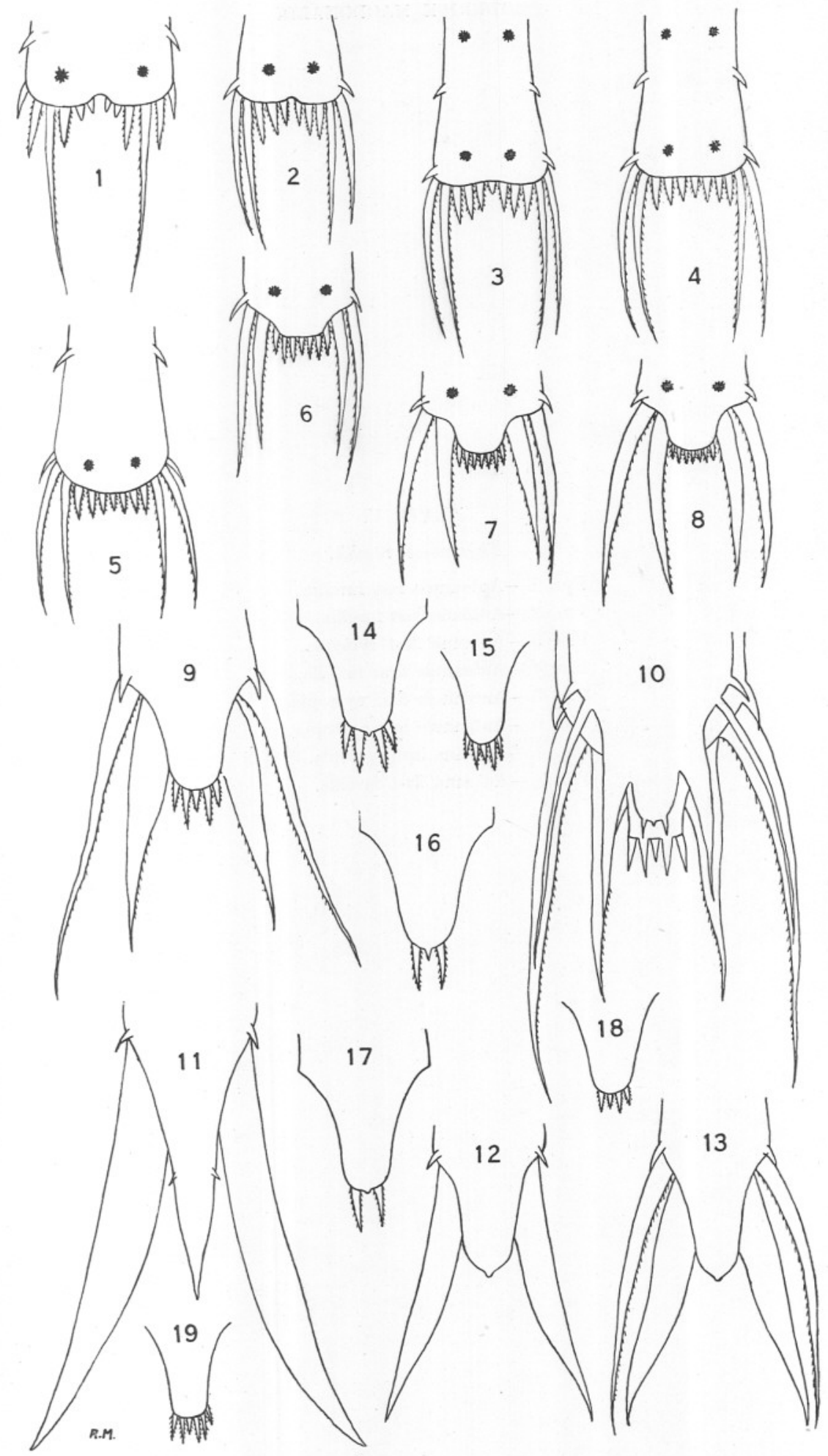
PLATE V.

Thysanoessa raschii.

Fig. 1.-Antennule last furcilia.

FIg. 2.-Antenna last furcilia.

FIG. 3.-Antenna first cyrtopia.

Fic. 4.-Antennule first furcilia.

Fic. 5.-Antennule first cyrtopia

Fig. 6.-Antennule last cyrtopia

Fig. 7.-Antenna last cyrtopia.

FrG. 8.-Antenna first furcilia. 

PLATE VI.

Thysanoessa raschii.

FIG. 1.-First thoracic appendage first furcilia.

FIG. 2.-Mandible first calyptopis.

FIG. 3.-Second thoracic leg eighth furcilia.

FIG. 4.-Mandible adult $13 \mathrm{~mm}$. long.

FIg. 5.-Mandible last furcilia.

FIG. 6. - Seventh thoracic leg $\delta^{t}$ adult $13 \mathrm{~mm}$. long.

FIG. 7.-Second thoracic leg first cyrtopia.

FIG. 8.-First thoracic leg first cyrtopia.

FIG. 9.-Second thoracic leg twelfth furcilia.

FIG. 10.-First thoracic leg eighth furcilia.

FIG. 11.-First thoracic appendage of third calyptopis. 
PLATE VI.
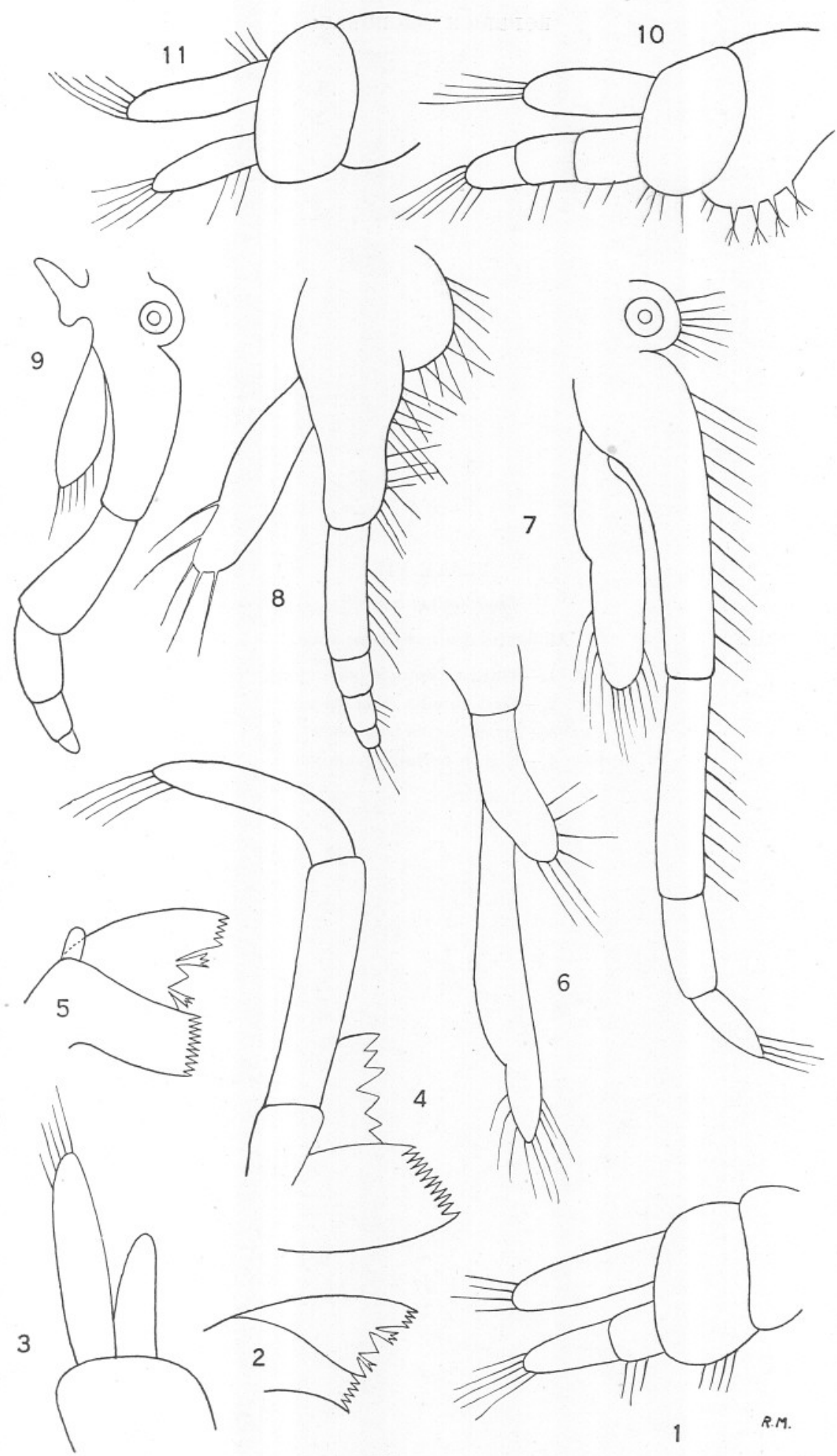
PLATE VII.

Thysanoessa raschii.

All figures drawn to same scale.

FIG. 1.-Third calyptopis (side view).

Fig. 2.-First furcilia (side view).

FIG. 3.- Sixth furcilia (side view).

FIG. 4.--Eighth cyrtopia (side view). 
PLATE VII.

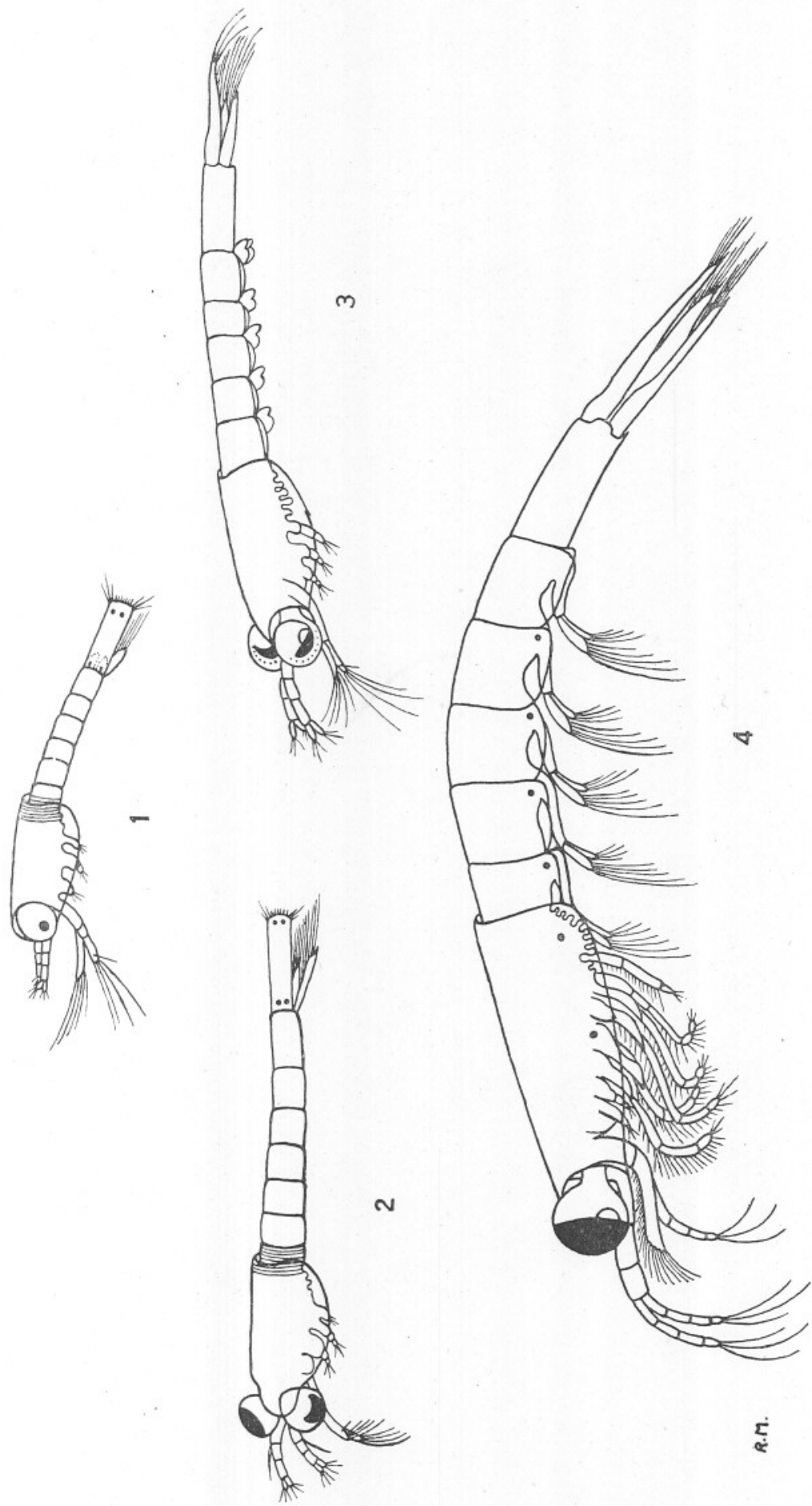


